\title{
Teaching Tense through Texts and Drills: Comparison of Test Scores
}

\section{THUNYAPAT WITCHUKRIANGKRAI}

Assumption College, Thailand

\section{Bio Data:}

Thunyapat Witchukriangkrai is currently teaching English for grade 10-11 English Program students at Assumption College Thailand.

\begin{abstract}
Comparison of Teaching Tense through Texts and Drills: A Case Study in Thailand was to study the effectiveness, the causes and advantages and disadvantages of the effects following from these teaching methods. Both grammar classes of grade 11 students of English Program Department of Assumption College Thonburi were taught by two different teaching methods, using texts and drills. They were tested by pre-test and post-test. The results and the opinions of both tests of both classes were compared. The students in the class taught by drills got higher development score; however, the other class already got high scores in their pre-test and we can't see much improvement from their score because there's not much chance to improve anymore. Moreover, the questionnaire asking about the students' opinions and suggestions about the tests expressed that one of the most possible way suggested is that teachers should choose the teaching styles which are appropriate with their own students according to some specific, individual factors of each class.
\end{abstract}

Keywords: teaching tense, teaching methods, texts and grammar drills, pre-test and post-test

\section{Introduction}

Clark argued that native-speakers listeners typically draw upon a range of comprehension strategies when they are listening. They focus on how syntactic and semantic strategies may be used to recover the meaning of what is heard in a rather improvisatory manner (as cited in Candlin \& Mercer, 2001). 
John Seely Brown, Adams Collins and Paul Duguid argued that Teaching is a matter of transmitting this knowledge, learning of receiving it accurately, storing it and using it appropriately (as cited in Biggs, 1996).

Therefore, to learn English in the same way that the native speakers of English do and use it appropriately, it might be a good idea to take a step back. Viewing situations or events from real use of language might help learners understand and absorb the way native speakers use the language. Short stories or novels containing situation sequencing, sets, scenes and actions of the characters in the story described deeply in detail are bound to encourage learners to be skilled by repetitively receiving a particular kind of input. However, teachers still need to explain and lead their ideas to focus on kinds of situations in which the particular tenses are used which support an implicit learning of tenses. Krashen has proposed (1985) that comprehensible input drives forward language development and generalizes to speaking was attractive. Claiming that we learn through exposure to meaningful material may not be very startling - we are unlikely to learn from material we do not understand, after all.

This essay was created to study the efficiency of two teaching methods; teaching through texts and grammar drills. Two classes of grade 11 students of English Program (EP), Assumption College Thonburi School; which include 11A and 11B, were selected. The grammar point chosen is the "Past Simple Tense VS Past Progressive" which is in the course outline. The class 11A was taught using example sentences in an excerpt; a chapter of a novel, while the class 11B was taught by the traditional grammar drills method using a material from a grammar book. Then 
their pre-test and post-test score results were considered to indicate their development of their understanding about the particular grammar point.

\section{Areas of the Study}

Two grade 11 classes from English Program of Assumption College Thonburi School were chosen. Most of them had been taught in English at least two years in main subjects such as Math, Science, History, Art, Computer, etc. Therefore, their English proficiency was appropriate to learn differences between the two mentioned tenses which can be considered quite difficult for intermediate students. They have some background knowledge of other easy tenses or at least they have probably known the structure of the particular tenses already; however, the usage of the two tenses was still unclear for them. Most intermediate students are often confused the usage of some particular sentences; Past Simple Tense vs. Past Progressive Tense, Past Simple Tense vs. Present Perfect Tense, Past Simple Tense vs. Past Perfect Tense, Past Perfect Tense vs. Past Perfect Progressive Tense, etc. According to the fact that the "differences between Past Simple Tense and Past Progressive Tense" fit with what had been planned in the course outline, this grammar point was selected.

\section{Methodology}

The students of the two classes were taught by different teaching methods; 11A through texts, 11B through drills. Firstly, they were tested by pre-test. Then the teacher taught past simple VS past progressive using the particular teaching methods. After the lessons were finished, the students, then, were tested again by the post-test. The results of both tests were compared and analyzed to study about the effectiveness of each teaching method. 


\section{Teaching Traditional Grammar Drills}

The students were taught using the handouts taken from "The Understanding of Grammar" by Betty Schrampfer Azar. It provided sentence structures, grammar rules, some example sentences, explanations and some gap-fill exercises emphasizing on the usage and the differences of both tenses.

At the beginning of the class, teacher explained the structures of the two tenses. Then, different situations in which they could use those tenses are provided. They were given different kinds of situations and cases that might cause them confusion. After that, they were asked to do some exercises which were gap-fill, creating sentences, etc.

\section{Teaching through Texts}

The students were given an excerpt of a chapter of "The Hound of Baskerville", one of the Sherlock Holmes' Adventures. Some particular sentences were highlighted to let the students try to deduct the rules and the usage of the two tenses by themselves. They were provided different kinds of situations which were able to be understood the happening sequences in the story. The students were asked about why those sentences had to be in those tenses and in what kind of situations we would use them. They were checked whether they understood by being asked to explain their understanding about what they had read to the class. Finally, let them tell stories or their own experiences using Past Simple Tense and Past Progressive Tense.

After the lessons were taught, due to the necessary of comparison of the pretest and the post-test; the tests were designed in similar patterns and level of 
difficulty. Both classes were tested by the same tests using the same amount of time after they had been taught by two different teaching methods. The Cloze technique was chosen to be used. All questions in both tests are gap-fill using the words provided in brackets. James Dean Brown (n.d.) suggested that:

All along, then, the K-R21 underestimates have been trying to tell me that there is something wrong with the way cloze tests function. I think I can now characterize cloze tests as a test development technique, wherein we more or less randomly develop items in sufficient numbers so that, even though many of them do not function well, the test appears to be at least moderately reliable.

Joseph Bartow Stubbs (1974) stated “We are convinced that the cloze technique represents an extremely useful evaluative tool for ESL specialists."

\section{Pre-test \& Post-test}

The students were tested with the pre-test designed with the main focus on differences between both tenses. It consisted of two parts presenting different kinds of questions that the students need to deal. Part I was to let the students fill in the gaps which were in a narrative paragraph, which the students had to understand the situations occurring in the paragraph and the actions that the subjects of the sentences do to be able to put in their answers. Part II was to let the students fill in the gaps in different sentences. They still had some clues or some key words letting them have some ideas of what tenses they should use; however, they were not provided the idea of sequences of situations and actions occurring so they could imagine or think as stimulation. Both parts in the both tests consisted and compounded by the vocabularies and grammar they had already learned. It emphasized on different aspects of using the two mentioned tenses. The total score 
of the first part was 20 and the second part was 10. According to limited time, the tests were designed to be as short as possible but still able to assess their proficiency. They had 15 minutes to finish the tests. As the first part was a narrative paragraph, it had to be in enough length to narrate story and present enough details to the students.

\section{Results}

The pre-test, post-test scores were quite various according to each students' learning ability. The pre-test scores were showed in the following table;

\section{Pre-test Scores of Class 11A (Teaching through texts)}

Table 1

Class 11A Pre-test Scores

\begin{tabular}{|l|l|l|l|l|}
\hline \multirow{2}{*}{ No. } & \multirow{2}{*}{ Student's Name } & \multicolumn{3}{|l|}{ Pre-test } \\
\cline { 3 - 5 } & & Part I & Part II & Total \\
$\mathbf{( 2 0 )}$ & $\mathbf{( 1 0 )}$ & $\mathbf{( 3 0 )}$ \\
\hline 1 & Tanapath & 17 & 8 & 25 \\
\hline 2 & Samrit & 16 & 7 & 23 \\
\hline 3 & Konokpathai & 18 & 8 & 26 \\
\hline 4 & Nateethorn & 15 & 1 & 16 \\
\hline 5 & Apimook & 15 & 7 & 22 \\
\hline 6 & Sittitat & 12 & 3 & 15 \\
\hline 7 & Woratad & 14 & 8 & 22 \\
\hline 8 & Patiharn & 16 & 0 & 16 \\
\hline 9 & Chanachon & 15 & 7 & 22 \\
\hline
\end{tabular}




\begin{tabular}{|l|l|l|l|l|}
\cline { 2 - 5 } 10 & Sureeporn & 18 & 6 & 24 \\
\hline 11 & Noppasorn & 17 & 7 & 24 \\
\hline 12 & Nat & 11 & 3 & 14 \\
\hline 13 & Sartnuphon & 15 & 3 & 18 \\
\hline 14 & Vasinee & 15 & 3 & 18 \\
\hline \multicolumn{2}{|l|}{ Average } & $\mathbf{1 5 . 2 8 5 7 1}$ & $\mathbf{5 . 0 7 1 4 2}$ & $\mathbf{2 0 . 3 5 7 1 4}$ \\
\hline \multicolumn{2}{|l|}{ Total Score } & $\mathbf{2 1 4}$ & $\mathbf{7 1}$ & $\mathbf{2 8 5}$ \\
\hline
\end{tabular}

According to the results shown in Table 1, most of the students did quite well in the part I. This might be because most of them had been studying in English for many years and also using English as their main language in class. However, there were six students who got their pre-test scores lower than five out of ten because of many reasons; some of them had low proficiency, some of them were late for the class so they were in a very hurry to do the test. From the pre-test results, we can see that this group of students had already been quite good before they had taken the teaching.

Table 2

Class 11B Pre-test Scores

\begin{tabular}{|c|l|c|c|c|}
\hline \multirow{2}{*}{ No. } & \multirow{2}{*}{ Student's Name } & \multicolumn{3}{|c|}{ Pre-test } \\
\cline { 3 - 5 } & & Part I & Part II & Total \\
\hline 1 & Techinee & (20) & (10) & (30) \\
\hline 2 & Tachakorn & 11 & 3 & 14 \\
\hline
\end{tabular}




\begin{tabular}{|c|l|c|c|c|}
\cline { 2 - 4 } 3 & Lookmoo & 14 & 4 & 18 \\
\hline 4 & Yinni & 19 & 5 & 24 \\
\hline 5 & Nithida & 12 & 6 & 18 \\
\hline 6 & Pimpika & 13 & 2 & 15 \\
\hline 7 & Pinprom & 12 & 4 & 16 \\
\hline 8 & Kunagon & 13 & no result & 13 \\
\hline 9 & Point & 12 & 5 & 17 \\
\hline 10 & Tadarat & 13 & 5 & 18 \\
\hline 11 & Kodchakorn & 14 & 3 & 17 \\
\hline 12 & Patchalida & $\mathbf{1 5 4}$ & $\mathbf{4 8}$ & $\mathbf{2 0 2}$ \\
\hline & Average & & & 13 \\
\hline & Total Score & & & \\
\hline & & & & \\
\hline
\end{tabular}

This is the results of class $11 \mathrm{~B}$ which were taught through grammar drills. Their average score were a little lower than class 11A's scores. However, the number of the students who got their scores lower than five out of ten was just five of them. There was one late student in this class, Kunagon, because the teaching began right after their mid-term examination so most of them just wait until the end of the exam time.

\section{Post-test Scores of Class 11A (Teaching through Texts)}

Table 3

Class 11A Post-test Scores

\begin{tabular}{|l|l|l|}
\hline No. & Student's Name & Post-test \\
\hline
\end{tabular}




\begin{tabular}{|c|c|c|c|c|}
\hline & & Part I (20) & Part II (10) & Total (30) \\
\hline 1 & Tanapath & 20 & 9 & 29 \\
\hline 2 & Samrit & 18 & 7 & 25 \\
\hline 3 & Konokpathai & 18 & 9 & 27 \\
\hline 4 & Nateethorn & 15 & 6 & 21 \\
\hline 5 & Apimook & 16 & 8 & 24 \\
\hline 6 & Sittitat & 13 & 5 & 18 \\
\hline 7 & Woratad & 17 & 6 & 23 \\
\hline 8 & Patiharn & 18 & 7 & 25 \\
\hline 9 & Chanachon & 16 & 7 & 23 \\
\hline 10 & Sureeporn & 14 & 6 & 20 \\
\hline 11 & Noppasorn & 10 & 8 & 18 \\
\hline 12 & Nat & 15 & 5 & 20 \\
\hline 13 & Sartnuphon & 11 & 7 & 18 \\
\hline 14 & Vasinee & no result & no result & no result \\
\hline \multicolumn{2}{|c|}{$\begin{array}{ll}\text { Average } \\
\end{array}$} & 14.35714 & 6.428571 & 20.78571 \\
\hline & Total Score & 201 & 90 & 291 \\
\hline
\end{tabular}

For the students who understood, they seemed to be able to get the idea of the differences really deeply clear. As we can see that there were several students were almost able to reach the full score, although some students became more confused and got lower scores than their pre-test scores. 


\section{Post-test Scores of 11B (Teaching through Grammar Drills)}

Table 4

Class 11B Post-test Scores

\begin{tabular}{|c|c|c|c|c|}
\hline \multirow[b]{2}{*}{ No. } & \multirow[b]{2}{*}{ Student's Name } & \multicolumn{3}{|c|}{ Post-test } \\
\hline & & Part I (20) & Part II (10) & $\begin{array}{c}\text { Total } \\
\text { (30) }\end{array}$ \\
\hline 1 & Techinee & 16 & 8 & 24 \\
\hline 2 & Tachakorn & 14 & 8 & 22 \\
\hline 3 & Lookmoo & 15 & 7 & 22 \\
\hline 4 & Yinni & 16 & 9 & 25 \\
\hline 5 & Nithida & 16 & 8 & 24 \\
\hline 6 & Pimpika & 16 & 8 & 24 \\
\hline 7 & Pinprom & 14 & 7 & 21 \\
\hline 8 & Kunagon & 13 & 9 & 22 \\
\hline 9 & Point & 14 & 7 & 21 \\
\hline 10 & Tadarat & 14 & 6 & 20 \\
\hline 11 & Kodchakorn & 16 & 7 & 23 \\
\hline 12 & Patchalida & no result & no result & no result \\
\hline & Average & 13.66666 & 7 & 20.66666 \\
\hline & Total Score & 164 & 84 & 248 \\
\hline
\end{tabular}

The post-test scores of class 11B were interesting. They understood more of choosing words to fill in sentences rather than in a narrative paragraphs. Moreover, 
the improvement from pre-test to post-test of class 11B was a lot from the second part of the test, which might be implied that they remember the rules and use their fresh memory to do the post-test.

\section{Comparison}

To make the efficiency of the two teaching methods become clear, comparing the results of each part from each test was done. However, for more information and to make the results interpretation more reasonable, the questionnaire asking about the students' opinions were created as a survey. We can see that after the teaching students got more scores in both parts; part I and part II. There is a great difference between Grade 11B's pre-test and post-test scores, especially those in part I, which leads to an assumption that teaching grammar through drills is effective and appropriate for this class.

The tests were created by far wishing to make them have equal level of difficulty; nevertheless, most of the students thought that they are not equal. There were four students of class 11A thinking that the pre-test was easier than the posttest, while another four of them thought that the post-test was easier. Surprisingly, another four students thought the both tests were equal. On the other hand, class $11 \mathrm{~B}$ students seemed to feel more comfortable doing the post-test. There are five students from this class thinking that the post-test was easier. Another five students thought that the both tests were equal.

The vocabulary in the tests was another fact the effects their score results. While four students from 11A thought that the vocabularies in the post-test were 
easier, there were just two students from class 11B thinking that the vocabularies in the post-test were easier.

Apart from vocabulary, another factor causing the test results is the difficulty of the grammar structure in the sentences in the tests. The most of the students from both classes thought that the grammar structure in the post-test was more complicated and more difficult than the pre-test.

Another important cause of being unable to do the test was that some students still cannot get rid of the effect from their first language (Thai) which does have the change of verb forms. Therefore, some of them did not put the verb in correct tense form and some got confused of using the tense form. For example, they wrote "weared" instead of "wore". One of the students stated in his questionnaire.

According to the information from the questionnaire, it might be able to assume that the reason why the class $11 \mathrm{~B}$ has more development than class $11 \mathrm{~A}$ is that they had quite much lower English language skill at the beginning. It was easier for them to gain something new and improve in widely range of score. From their score results, we might be able to assume that the students getting their scores in range of 13-18 in their pre-test got a lot of higher score in their post-test. As we can see that Nateetorn a student from 11A got 16 points in his pre-test and got 21 points in his post-test. Pinprom and Tachakorn, for example, from 11B, they got their pretest score in the range of $13-18$ points and got their post-test $21-24$ points. On the other hand, most of the students who got quite good score in their pre-test, it was hard for them to get a lot of developed scores. For example, Tanapath got 25 in his 
pre-test and got 29 in his post-test. Kanokpatai got 26 in his pre-test, 27 in his posttest.

According to the students' opinions and suggestions in the questionnaire asking about the pre-test and post-test, the feedback from the students are not much various. One of the students from class11A stated that "It's a very good lesson, hope to participate again soon." While another student asked for more practicing in class; "Need more exercises to practice, various kinds of situations." Another one student asked the teacher to give some explanations before the teacher would start the lesson "Give/ explain vocabularies first because it will help students understand more when they read passages.", "The explanation is good enough for me to understand, but I need more specific detail such as why should do that, when should do that, how should do that, why can't do this, etc. To make the student completely understand and be able to do all the exercise or test is give more variety type of exercise for practicing their ability to do the test."

There is only one student who wrote an opinion from class 11B. He suggested that "More examples and exercises to do together with the teacher. This will provide more understanding for us."

From the quotation of students' opinions and suggestions above, both classes asked for more exercises to practice. While, a student from class 11A asked for vocabulary explanation before they would take the tests. One of them also expressed that they still have some confusions about how to use it.

\section{Advantages and Disadvantages of Teaching through Texts and Drills}

Teaching through texts and drills has some different advantages and disadvantages depending on its use.

Table 5 
Advantages and Disadvantages of Teaching through Texts and Drills

\begin{tabular}{|c|c|c|}
\hline & Through texts & Drills \\
\hline Advantages & $\begin{array}{l}\text { - Students who could } \\
\text { understand the ideas of } \\
\text { how to use the tenses } \\
\text { would be able to } \\
\text { understand really deeply } \\
\text { and clearly because the } \\
\text { students were provided } \\
\text { enough background } \\
\text { knowledge about the } \\
\text { sequencing in the story. }\end{array}$ & $\begin{array}{l}\text { - Straight to the point and } \\
\text { save time, so the teacher } \\
\text { could teach or move to } \\
\text { other topics faster. }\end{array}$ \\
\hline Disadvantages & $\begin{array}{l}\text { - } \text { Some students usually } \\
\text { don't read the story } \\
\text { before they come to class } \\
\text { causing the teacher got } \\
\text { frustrated and need to } \\
\text { spend more time on } \\
\text { explaining the situations } \\
\text { in the story before } \\
\text { teaching. }\end{array}$ & $\begin{array}{l}\text { - Students might be able to } \\
\text { remember how to use the } \\
\text { tenses but it doesn't } \\
\text { mean that they really } \\
\text { understand. } \\
\text { Poor students might not } \\
\text { be able to follow up their } \\
\text { friends and be } \\
\text { demotivated. }\end{array}$ \\
\hline
\end{tabular}




\section{Conclusion}

In conclusion, each teaching method has its own advantages and disadvantages. Teaching tenses using drills method was very effective. As we can see that the students from 11B got their post-test scores higher than their pre-test's. We can assume that the particular teaching is able to help students understand well in a very quick way, and save time. However, teaching through texts by using an excerpt from a story can also be effective in helping students understand the tenses.

Teaching through texts might be a good way to learn English for the students, but they are not all like reading and preparing before they come to class. While drills suits those mentioned kind of students more than teaching through texts. Some weak students might not like the teaching through text style because it is hard for them to keep up with their friends and most of the time they feel awkward to ask teachers several questions.

For further study, it might be a good idea if the students in two classes are swopped the teaching methods; teach class $11 \mathrm{~A}$ with drills and teach class $11 \mathrm{~B}$ through texts. Both teaching methods might be mixed and used for teaching together in both two classes to find out factors contributing to the students' success in their grammar learning.

In my opinion, I can see a lot of advantages of both teaching through texts and drills. The teacher him/herself should choose the teaching method suiting their course, class size, age of students, or time limitation. The use of technology should also be taken under consideration in order to suit various students' learning styles. 


\section{References}

Biggs, J. (1996). Enhancing teaching and learning through constructive alignment. Higher Education, 32, 347-364.

Celce-Murcia, M. (1998). Techniques and resources in teaching grammar. Oxford: Oxford University Press.

Frankland, S. (2007). Enhancing teaching and learning through assessment: Deriving an appropriate model. Retrieved from http:/ / www.springerlink.com/content/978-1-4020-6226$1 \#$ section=190841\&page $=4 \&$ locus $=34$

Gerngross, G. (2007). Teaching grammar creatively. Cambridge: Cambridge University Press.

Larsen-freeman, D. (2003). Teaching language. Boston: Thompon Heinle.

Nunan, d. (2005). Practical English language teaching. New York: McGraw-Hill.

Stubbs, J. B. (1974).The cloze test as a measure of English proficiency. The Modern Language Journal, 58, 239-241.

\section{Appendix}

\section{Past Simple Tense vs. Past Progressive Tense}

(Pre-test)

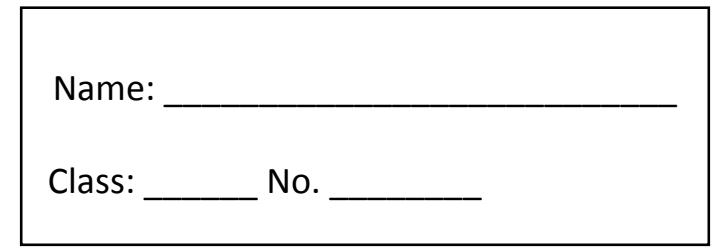

Instruction: Fill in the gaps using Past Simple Tense or Past Progressive Tense with the verb provided in the brackets. 
James Ellis 1. (go) on a business trip last week. He 2. (visit) some customers in Frankfurt. He 3. (leave) home early on Monday morning and 4. (take) a taxi to the airport. He 5. (get) there at about 8 o'clock. He 6 . (check in) and 7. (go) to the airport lounge. He 8. (buy) a newspaper and 9. (go) to get acoffee. He10. (drink) his coffee when he

11. (see) an old friend, Bob. He12. (be) very surprised that

Bob 13. (be) in London and 14. (find out) that he 15. (start) a new job in the city. As they 16. (speak) they17. (hear) an announcement. "Would all passengers for the 9.30 flight to Frankfurt please go to boarding gate 10". James18. (say) goodbye to Bob and as they 19 . (leave) Bob 20. (give) him his business card and asked him to phone when he returned from Frankfurt.

Instruction: Fill in the gaps using Past Simple Tense or Past Progressive Tense with the verb provided in the brackets.

1. Who (you talk) $\longdiv { }$ to on the phone when I arrived?

2. While I was swimming someone (steal)

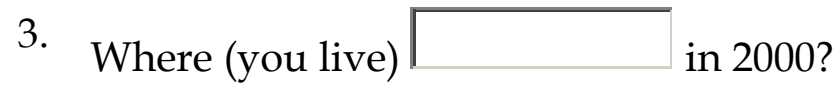

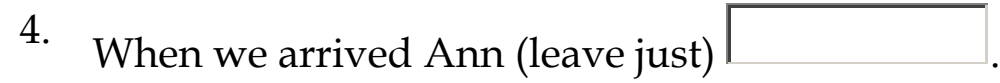

5. What (you do)

6. What (you do) at 6 o'clock in the morning? 


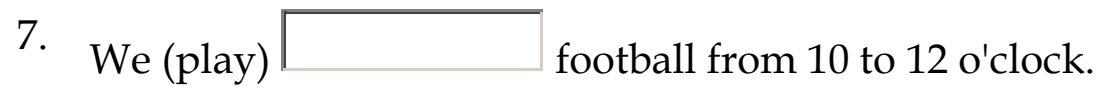

8. The sun (shine)

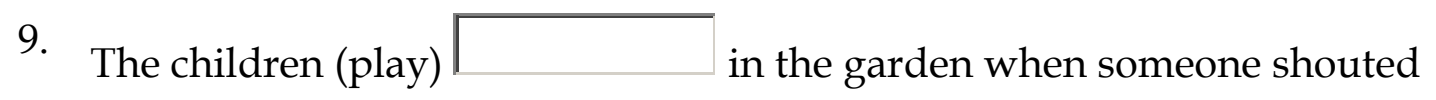
very loudly.

10. Mary (wear) a very nice coat at the party yesterday.

\section{Past Simple Tense vs. Past Progressive Tense}

(Post-test)

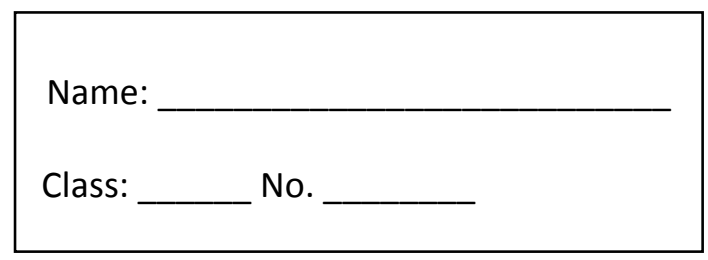

Instruction: Fill in the gaps using Past Simple Tense or Past Progressive Tense with the verb provided in the brackets.

After 1. (board) James 2. (put) his briefcase in the overhead locker and3. (sit) down. During the flight, James4. (do) some paper work and 5. (speak) to the woman sitting next to him, while they 6 . (speak) the flight attendant 7. (bring) breakfast. When the plane 8 . (land) in London, it was almost 11 o'clock. James 9. (take) a train to his hotel. Then he10. (walk) to the customer's office. He 11. (get) there at $1.00 \mathrm{pm}$ and12. (go) to the reception desk. The receptionist 13. (ask) him to wait. Whilst he14. (wait) she

15. (offer) him a drink. He and his customer 16. (talk) all afternoon. When Bob 17. (get) to his hotel at 7 o'clock that night, 
he18. (phone) his wife and then 19 (go) to the hotel restaurant. He 20. (go) to bed at $10 \mathrm{pm}$.

Instruction: Fill in the gaps using Past Simple Tense or Past Progressive Tense with the verb provided in the brackets.

1. Jenny (fall asleep) $\quad$ while she was watching an interesting film.

2. I was waiting for my sister when it (start)

3. I called Peter and then I (go)

4. I (wash) $\longrightarrow$ my hair when I realized I hadn't phoned Katie.

5. I (walk) $\longrightarrow$ along the street when I met my ex-wife.

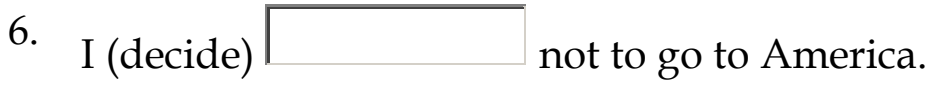

7. He said that he (be) $\longdiv { \square }$ on holiday.

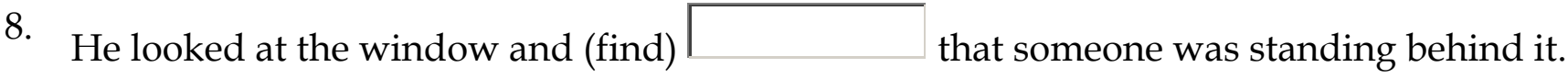

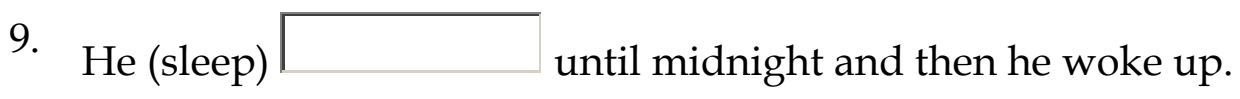

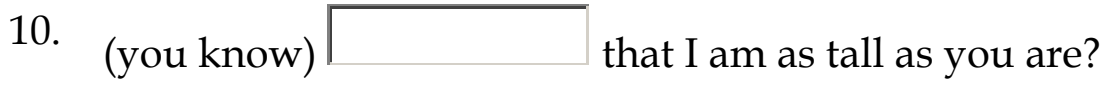




\section{Tables and Figures}

Table 1

Class 11A Pre-test Scores

\begin{tabular}{|c|c|c|c|c|}
\hline \multirow[b]{2}{*}{ No. } & \multirow[b]{2}{*}{ Student's Name } & \multicolumn{3}{|c|}{ Pre-test } \\
\hline & & $\begin{array}{l}\text { Part I } \\
\text { (20) }\end{array}$ & $\begin{array}{c}\text { Part II } \\
\text { (10) }\end{array}$ & $\begin{array}{c}\text { Total } \\
(30)\end{array}$ \\
\hline 1 & Tanapath & 17 & 8 & 25 \\
\hline 2 & Samrit & 16 & 7 & 23 \\
\hline 3 & Konokpathai & 18 & 8 & 26 \\
\hline 4 & Nateethorn & 15 & 1 & 16 \\
\hline 5 & Apimook & 15 & 7 & 22 \\
\hline 6 & Sittitat & 12 & 3 & 15 \\
\hline 7 & Woratad & 14 & 8 & 22 \\
\hline 8 & Patiharn & 16 & 0 & 16 \\
\hline 9 & Chanachon & 15 & 7 & 22 \\
\hline 10 & Sureeporn & 18 & 6 & 24 \\
\hline 11 & Noppasorn & 17 & 7 & 24 \\
\hline 12 & Nat & 11 & 3 & 14 \\
\hline 13 & Sartnuphon & 15 & 3 & 18 \\
\hline 14 & Vasinee & 15 & 3 & 18 \\
\hline & Average & 15.28571 & 5.07142 & 20.35714 \\
\hline & Total Score & 214 & 71 & 285 \\
\hline
\end{tabular}


Table 2

Class 11B Pre-test Scores

\begin{tabular}{|c|c|c|c|c|}
\hline \multirow[b]{2}{*}{ No. } & \multirow[b]{2}{*}{ Student's Name } & \multicolumn{3}{|c|}{ Pre-test } \\
\hline & & $\begin{array}{l}\text { Part I } \\
\text { (20) }\end{array}$ & $\begin{array}{c}\text { Part II } \\
\text { (10) }\end{array}$ & $\begin{array}{l}\text { Total } \\
(30)\end{array}$ \\
\hline 1 & Techinee & 11 & 3 & 14 \\
\hline 2 & Tachakorn & 14 & 5 & 19 \\
\hline 3 & Lookmoo & 14 & 4 & 18 \\
\hline 4 & Yinni & 19 & 5 & 24 \\
\hline 5 & Nithida & 12 & 6 & 18 \\
\hline 6 & Pimpika & 13 & 2 & 15 \\
\hline 7 & Pinprom & 12 & 4 & 16 \\
\hline 8 & Kunagon & 13 & no result & 13 \\
\hline 9 & Point & 12 & 5 & 17 \\
\hline 10 & Tadarat & 13 & 5 & 18 \\
\hline 11 & Kodchakorn & 14 & 3 & 17 \\
\hline 12 & Patchalida & 7 & 6 & 13 \\
\hline & Average & 12.83333 & 4 & 16.83333 \\
\hline & Total Score & 154 & 48 & 202 \\
\hline
\end{tabular}


Table 3

Class 11A Post-test Scores

\begin{tabular}{|c|c|c|c|c|}
\hline \multirow{2}{*}{ No. } & \multirow{2}{*}{ Student's Name } & \multicolumn{3}{|c|}{ Post-test } \\
\hline & & Part I (20) & Part II (10) & Total (30) \\
\hline 1 & Tanapath & 20 & 9 & 29 \\
\hline 2 & Samrit & 18 & 7 & 25 \\
\hline 3 & Konokpathai & 18 & 9 & 27 \\
\hline 4 & Nateethorn & 15 & 6 & 21 \\
\hline 5 & Apimook & 16 & 8 & 24 \\
\hline 6 & Sittitat & 13 & 5 & 18 \\
\hline 7 & Woratad & 17 & 6 & 23 \\
\hline 8 & Patiharn & 18 & 7 & 25 \\
\hline 9 & Chanachon & 16 & 7 & 23 \\
\hline 10 & Sureeporn & 14 & 6 & 20 \\
\hline 11 & Noppasorn & 10 & 8 & 18 \\
\hline 12 & Nat & 15 & 5 & 20 \\
\hline 13 & Sartnuphon & 11 & 7 & 18 \\
\hline 14 & Vasinee & no result & no result & no result \\
\hline & Average & 14.35714 & 6.428571 & 20.78571 \\
\hline & Total Score & 201 & 90 & 291 \\
\hline
\end{tabular}


Table 4

Class 11B Post-test Scores

\begin{tabular}{|c|c|c|c|c|}
\hline \multirow[b]{2}{*}{ No. } & \multirow[b]{2}{*}{ Student's Name } & \multicolumn{3}{|c|}{ Post-test } \\
\hline & & Part I (20) & Part II (10) & $\begin{array}{c}\text { Total } \\
(30)\end{array}$ \\
\hline 1 & Techinee & 16 & 8 & 24 \\
\hline 2 & Tachakorn & 14 & 8 & 22 \\
\hline 3 & Lookmoo & 15 & 7 & 22 \\
\hline 4 & Yinni & 16 & 9 & 25 \\
\hline 5 & Nithida & 16 & 8 & 24 \\
\hline 6 & Pimpika & 16 & 8 & 24 \\
\hline 7 & Pinprom & 14 & 7 & 21 \\
\hline 8 & Kunagon & 13 & 9 & 22 \\
\hline 9 & Point & 14 & 7 & 21 \\
\hline 10 & Tadarat & 14 & 6 & 20 \\
\hline 11 & Kodchakorn & 16 & 7 & 23 \\
\hline 12 & Patchalida & no result & no result & no result \\
\hline & Average & 13.66666 & 7 & 20.66666 \\
\hline & Total Score & 164 & 84 & 248 \\
\hline
\end{tabular}


Table 5

Advantages and Disadvantages of Teaching through Texts and Drills

\begin{tabular}{|c|c|c|}
\hline & Through texts & Drills \\
\hline Advantages & $\begin{array}{l}\text { - Students who could } \\
\text { understand the ideas of } \\
\text { how to use the tenses } \\
\text { would be able to } \\
\text { understand really deeply } \\
\text { and clearly because the } \\
\text { students were provided } \\
\text { enough background } \\
\text { knowledge about the } \\
\text { sequencing in the story. }\end{array}$ & $\begin{array}{l}\text { - Straight to the point and } \\
\text { save time, so the teacher } \\
\text { could teach or move to } \\
\text { other topics faster. }\end{array}$ \\
\hline Disadvantages & $\begin{array}{l}\text { - } \text { Some students usually } \\
\text { don't read the story } \\
\text { before they come to class } \\
\text { causing the teacher got } \\
\text { frustrated and need to } \\
\text { spend more time on } \\
\text { explaining the situations } \\
\text { in the story before } \\
\text { teaching. }\end{array}$ & $\begin{array}{l}\text { - Students might be able to } \\
\text { remember how to use the } \\
\text { tenses but it doesn't } \\
\text { mean that they really } \\
\text { understand. } \\
\text { Poor students might not } \\
\text { be able to follow up their } \\
\text { friends and be } \\
\text { demotivated. }\end{array}$ \\
\hline
\end{tabular}

